\title{
Familial hypoaldosteronism
}

INSERM

\section{Source}

INSERM. (1999). Orphanet: an online rare disease and orphan drug data base. Familial hypoaldosteronism. ORPHA:427

Aldosterone synthase deficiency is a rare inherited defect of the final step of aldosterone biosynthesis (conversion of deoxycorticosterone to aldosterone). 